\title{
БРОНЗОВЫЕ ЗЕРКАЛА ИЗ ТАЛЬХИРА КАК ИСТОЧНИК ПО МАТЕРИАЛЬНОЙ КУЛЬТУРЕ: ИССЛЕДОВАНИЯ И.И. КОПЫЛОВА
}

\author{
(C) 2021 г. Мухтарова Гульмира Раиловна ${ }^{1}$, \\ Железняков Борис Анатольевич ${ }^{2}$ Жумай Гульмира ${ }^{1}$
}

\footnotetext{
${ }^{1}$ кандидат исторических наук, директор, Государственный историко-культурный заповедник-музей «Иссык», г. Есик, Казахстан. E-mail: railovna@mail.ru 2автор-корреспондент, старший научный сотрудник, Институт археологии им. А.X. Маргулана, г. Алматы, Казахстан. E-mail: boriszheleznyakov@mail.ru ${ }^{1}$ старший научный сотрудник, Государственный историко-культурный заповедник-музей «Иссык», г. Есик, Казахстан. E-mail: jboti@mail.ru
}

Аннотация. Публикация основана на архивных материалах И.И. Копылова о месте и условиях находки бронзовых зеркал, данных анализов о составе металла. Проводится анализ опубликованных ранее данных по бронзовым зеркалам, происходящих из городища Талгар. Тем самым, на основе архивных данных исследователя средневекового памятника, ставится и во многом решается вопрос о местном производстве зеркал на местном же сырье. Ранее опубликованные статьи фактически ставили вопрос только об этнокультурной принадлежности орнаментального сюжета, из которого состоит рельефно-орнаментированная тыльная сторона зеркала, то есть - о культурных истоках, распространенных в то время на Великом Шелковом пути орнаментов. Детали обнаружения зеркал в культурном слое, принадлежности руин построек крайне важны для реконструкции культурных контактов, а главное, для понимания высокого уровня развития ремесла на Талгаре в XI - первой половине XIII в., роли и месте ювелира и торевта в ремесленной «табели о рангах» Тальхиза, чьи богатые жилища и развитые производства располагались в центре города. Приводятся некоторые данные о сопровождающих находки зеркал в мастерских: массовых артефактах, орудиях, штампах.

Ключевые слова: археология, городище Талгар, ремесленное производство XII - начала XIII в., бронзовое литье, состав бронз, средневековые зеркала

\section{МАТЕРИАЛДЫК МӘДЕНИЕТТІН ҚАЙНАР КӨЗІ ТАЛЬХИР КОЛА АЙНАЛАРЫ: И.И. КОПЫЛОВ ЗЕРТТЕУЛЕРІ}

\section{Мұхтарова Гүлмира Райылқызы ${ }^{1}$, Железняков Борис Анатольевич ${ }^{2}$, Жұмай Гүлмира ${ }^{1}$}

${ }^{1}$ тарих ғылымдарының кандидаты, директор, «Есік» мемлекеттік тарихи-мәдени қорық-музейі,Есік қ., Қазақстан. E-mail: railovna@mail.ru

${ }^{2}$ корреспондент авторы, аға ғылыми қызметкер, Ә.Х. Марғұлан атындағы Археология институты,Алматы қ., Қазақстан. E-mail: boriszheleznyakov@mail.ru

${ }^{1}$ аға ғылыми қызметкер, «Есік» мемлекеттік тарихи-мәдени қорық-музейі, Есік к., Қазақстан. E-mail: jboti@mail.ru

Аннотация. Мақалада И.И. Копыловтың архив деректері негізінде қола айналардың табылған орындары, қоланың құрамына жасалған талдама мәліметтері туралы айтылады. Талғардан табылған қола айналар туралы бұрын жарияланған деректермен қатар аталмыш мәселелерді зерттеушілерге талдау жүргізіледі. Сондайақ, ортағасырлық ескерткішті зерттеушілердің мұрағаттық деректері негізінде айнаны 
өндіруге жергілікті шикізатты қолдану мәселелері де көтеріледі. Бұрын жарияланған мақалаларда айна бетіндегі өрнектердегі сюжеттің этномәдени байланысы туралы ғана айтылса, мақалада айнаның артқы жағындағы мәдени бастаулар, ою-өрнектер Ұлы Жібек жолында кең таралғандығы туралы да қарастырылады. Мәдени қабаттағы айна бөлшектерінің табылуы ғимарат қирандыларына қатысты мәдени байланыстарды қалпына келтіру, сондай-ақ, XI-XIII ғғ Талғар қалашығындағы қолөнердің жоғары деңгейде дамуын түсіну үшін өте маңызды. Талхиздегі зергерлер мен торевтердің қолөнердегі «деңгейінің» рөлі мен орнын қаланың дәл орталығында орналасқан бай тұрғын үйлер мен дамыған өндірістен көруге болады. Шеберханаларда айналар табылған кезде қосымша кейбір мәліметтер келтірілген: жалпы артефактілер, құралдар және мөртабандар.

Түйін сөздер: археология, Талғар қалашығы, қола құйма, қола құрамы, ортағасырлық айна

\title{
BRONZE MIRRORS FROM TALHIR AS A SOURCE ON MATERIAL CULTURE: RESEARCH BY I.I. KOPYLOV
}

\section{Mukhtarova Gulmira ${ }^{1}$, ZheleznyakovBoris ${ }^{2}$, Zhumai Gulmira ${ }^{1}$}

${ }^{1}$ Candidate of historical sciences, director, Issyk State Historical and Cultural Reserve-Museum, Esik, Kazakhstan. E-mail: railovna@mail.ru ${ }^{2}$ Corresponding author, senior Researcher, A.Kh. Margulan Archeology Institute, Almaty, Kazakhstan. E-mail: boriszheleznyakov@mail.ru

${ }^{1}$ Senior Researcher, Issyk State Historical and Cultural Reserve-Museum, Esik, Kazakhstan. E-mail: jboti@mail.ru

\begin{abstract}
The publication is based on the archival data of I.I. Kopylov on the place and conditions of finding of bronze mirrors, analysis data on the composition of bronzes. An analysis of previously published data on bronze mirrors originating from the Talgar settlement is being carried out. Thus, based on the archival data of the researcher of the medieval site, the issue of local production of mirrors from local raw materials is raised and resolved. Previously published articles actually raised the question only about the ethnocultural affiliation of the ornate plot, which is depicted on the relief-ornamented rear side of the mirror, that is, in fact about the cultural origins common at that time on the Great Silk Road ornaments. The details of the discovery of mirrors in the cultural layer, the belonging of the ruins of the buildings, are extremely important for the reconstruction of cultural contacts, and most importantly, for understanding the high level of craft development on Talgar in the $11^{\text {th }}$ - the first half of the $13^{\text {th }}$ centuries. Role and place of the jeweler and torewt in the craft "table of ranks" of Talhiz city, whose rich dwellings and developed industries were located right in the city center. Some details of the accompanying finds in the workshops are given: other mass artifacts, tools, stamps.
\end{abstract} mirrors

Keywords: archaeology, Talgar site, bronze casting, composition of bronzes, medieval

\section{Введение}

Городище Талгар - уникальный памятник городской культуры Илейской долины VIII-XIII вв., руины средневекового города Тальхира/ Тальхиза расположены вблизи крупнейшего мегаполиса Казахстана. Увлажненно-континентальный климат оазиса, который маркирует полоса чернозема у северных склонов Иле Алатау, имеет наибольшую ширину у Талгара. Обилие свежей воды спо-

собствовало тому, что город Тальхир возник на трассе Великого Шелкового пути как узловой пункт на развилке этого «коридора» с запада на северовосток: до Каялыка и озера Алаколь, а также на юго-восток - в сторону верховьев р. Иле. Помимо отдыха, восполнения запасов продуктов и фуража значительное распространение приобрели производства: керамическое [Кузнецова, 2007], железоделательное 
[Савельева и др., 1998], бронзовых и стеклянных изделий [Савельева, 2006]. К моменту начала исследования памятника В.Д. Городецким (20-е гг. XX в.) к городищу с разных сторон подходили цепочки курганов [Городецкий, 1928, с. 49-50].

Упоминание о первых находках на городище Талгар можно найти в работе А.Х. Маргулана и Е.И. Агеевой: «В 1929-1930 гг. на территории городища Талгар при случайных обстоятельствах была найдена глиняная печатка с изображением льва в растительном орнаменте», а также керамика XI-XII вв. Артефакты переданы в ЦГМ РК [Маргулан, Агеева, 1948, с. 125]. И.И. Копылов практически каждый год занимался исследованием курганов (1960-1980-е гг.) в расположенной рядом с городищем Глубокой щели [Копылов, 1987, с. 1-9]. Местность обладала значительным притяжением древнего и средневекового населения: удобна и для земледелия, культивировавшегося с усуньской эпохи. Приток населения к конусу выноса Талгара был связан не только с природноклиматическими условиями, но и с минеральной базой, что неоднократно отмечалось И.И. Копыловым [Копылов, 1987].

Изучениесредневекового городища проводилось И.И. Копыловым с 1955 г. до конца 1980-х гг. С конца 1970-х гг. исследования проводились им параллельно с К.М. Байпаковым и Т.В. Савельевой. Археологические исследования под руководством Т.В. Савельевой проводились до самого последнего времени, один из проектов реализовывался до 2020 г. [Камалдинов, Савельева, 2019; Савельева и др., 2020]. Значительное число зеркал было открыто на раскопах под руководством И.И. Копылова. Результаты
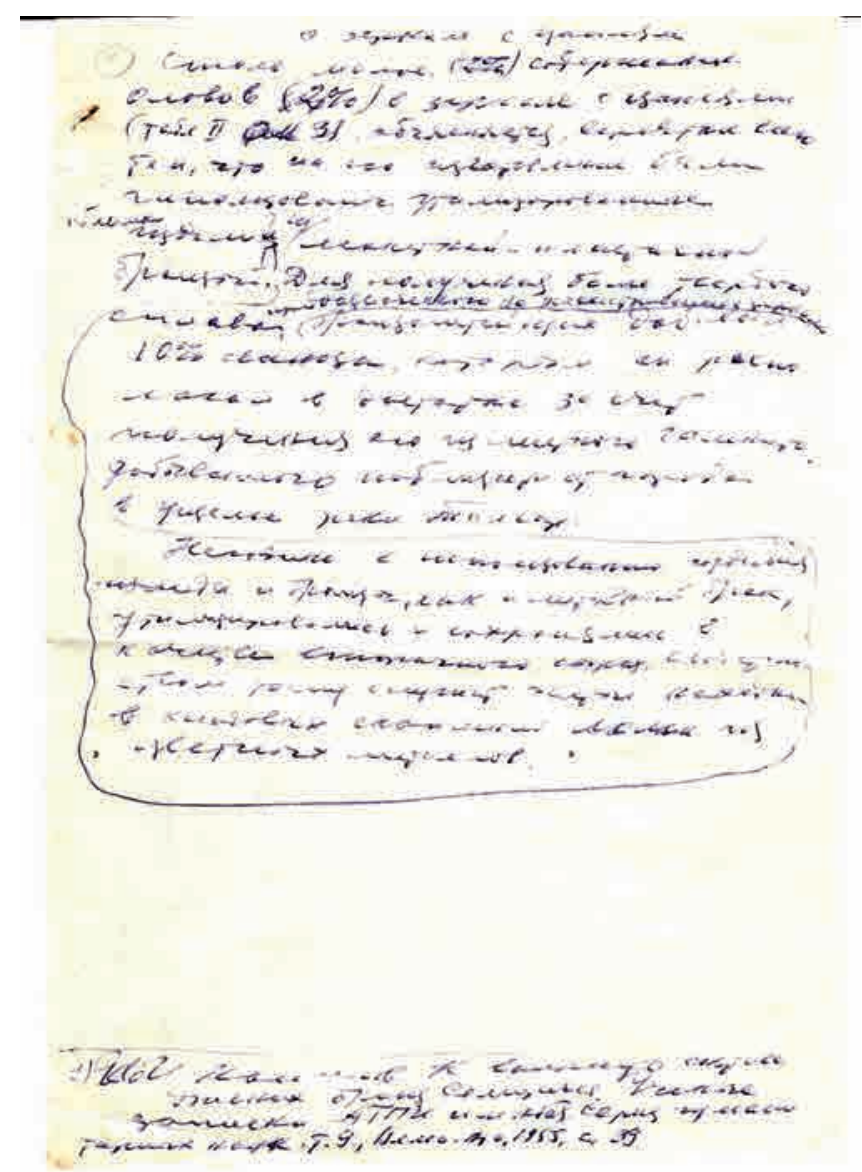

Рис. 1. Лист рукописи И.И. Копьлова (о прочентном содержании металлов в бронзовом сплаве). Из архива ГИК заповедника-музея "Иссык»

Fig. 1. Sheet of paper from the manuscript by I.I. Kopylov (about the percentage of metals in the bronze alloy). Archive of the State Historical Cultural Reserve-Museum of "Issyk" 
анализа состава бронзы зеркал однозначно свидетельствуют, по мнению И.И. Копылова, об их производстве по имевшимся образцам местными ремесленниками [Копылов, 1955] (рис. 1; табл. 1). С 2018 г. менеджмент памятника «Городище Талгар», внесенного в Список всемирного наследия в серийной и транснациональной номинации: «Шелковый путь: сеть маршрутов Чанъань-Тянь-Шанского коридора» (2014), осуществляет заповедник-музей «Иссык». комплекса материалов, связанных с изучением бронзовых зеркал, найденных, главным образом, при проведении археологических раскопок И.И. Копыловым в 1964-1981 гг. на Талгарском городище, а также случайных находок с территории памятника. Теоретические исследования проводились на основе систематизации с последующей реконструкцией вопросов, связанных с бронзолитейным производством, локализацией горнорудного производства, а также

\section{Таблица 1 - Результаты анализов зеркал Талгарского городища}

Table 1 - Results of analysis of mirrors from the Talgar site

\begin{tabular}{|c|c|c|c|c|c|c|c|c|c|c|c|c|c|c|c|}
\hline № & Предметы & $\mathrm{Cu}$ & $\mathrm{Sn}$ & $\mathrm{Pb}$ & $\mathrm{Zn}$ & $\mathrm{Bi}$ & $\mathrm{Ag}$ & $\mathrm{Sb}$ & $\mathrm{As}$ & $\mathrm{Fe}$ & $\mathrm{Mo}$ & $\mathrm{Mn}$ & $\mathrm{Au}$ & $\mathrm{V}$ & $\mathrm{Ca}$ \\
\hline 1 & $\begin{array}{c}\text { Зеркало } \\
\text { без } \\
\text { орнамента }\end{array}$ & 80 & 5 & 0,002 & 0,002 & 0,002 & 0,005 & - & - & 1,0 & - & - & - & - & - \\
\hline 2 & $\begin{array}{c}\text { Зеркало с } \\
\text { цветами }\end{array}$ & 60 & 15 & 20 & 0,02 & 0,05 & 0,01 & - & 0,05 & 0,1 & - & - & - & - & - \\
\hline 3 & $\begin{array}{c}\text { Зеркало с } \\
\text { птицами }\end{array}$ & 80 & 2 & 10 & 0,005 & 0,05 & 0,02 & - & - & 0,5 & - & - & - & - & - \\
\hline 4 & $\begin{array}{c}\text { Фрагмент } \\
\text { зеркала без } \\
\text { орнамента }\end{array}$ & 59,32 & 17,97 & 0,32 & 0,02 & - & 0,016 & - & 0,05 & 0,3 & 0,0007 & 0,038 & 0,002 & 1,10 & 2,05 \\
\hline 5 & $\begin{array}{c}\text { Половинка } \\
\text { зеркала с } \\
\text { надписью }\end{array}$ & 65 & 30 & 0,01 & 0,005 & 0,002 & 0,005 & - & 0,02 & 0,05 & - & - & - & - & - \\
\hline
\end{tabular}

Примечание: Анализы зеркал № 1-3, 5 выполнены до начала 1986 г. (заказчик - Копылов И.И.) лазерным локальным спектральным методом в Казахстанском филиале ВИРГ М.В. Бобровой; зеркала № 4 - рентгенофлюоресцентным методом в химической лаборатории АЗТМ В. Ширяевой.

Мы, при выполнении работы, не располагая самими артефактами для проведения анализов на современном уровне, приводим результаты анализов 1980-х гг. Восстанавливается «карта артефактов» городища Талгар.

Основные методы проведения исследований

В результате исследований выполнено теоретическое осмысление культурных связей Илейского участка Великого Шелкового пути.

Сличение материалов публикаций К.М. Байпакова [Байпаков и др., 2005; Байпаков, 2012] и К.Ю. Марковой [Маркова, 2013] с данными архива И.И. Копылова [Копылов, 1986], хранящегося в фондах Государственного историко-культурного заповедникамузея (ГИКЗМ) «Иссык», показывает, что И.И. Копыловым было найдено основное число зеркал на городище 
(шесть целых зеркал, большинство из которых было найдено в культурном слое). Архивные материалы заполняют пробелы в знаниях об исследованиях памятника: место и время находки зеркал; то обстоятельство, что значительное число зеркал найдено в «доме ювелира» и «доме торевта» может наводить на мысль об их местном производстве по образцам, декор которых соответствует другим культурам. И.И. Копылову на основании проведённых анализов и знаний месторасположения и особенностей ближайших рудных запасов удалось это доказать [Копылов, 1988].

Публикация результатов анализов проб бронзы этих зеркал, проведенных до 1986 г., была осуществлена автором лишь однажды в малоизвестном издании [Копылов, 1988], но не была отражена во многих последующих публикациях К.М. Байпакова. Справедливости ради необходимо отметить, что результаты анализов несколько разнятся по содержанию основного компонента, но не тех компонентов (главным образом - висмута), которые определяют локализацию месторождения в широком диапазоне. К настоящему времени известно местонахождение лишь двух зеркал, находящихся в экспозиции Музея «Центр сближения культур», местонахождение других зеркал нам не известно. Многие (если не большинство) артефакты из коллекции И.И. Копылова «канули» после его смерти в 1993 г. ваний

Описание материалов исследо-

Зеркала из Талгарского городища публиковались неоднократно без определенной привязки (как места находки и экспонирования). К.М. Байпаков считал их произведенными в
Иране или Средней Азии, приводя относительно подробное описание [Байпаков и др., 2005, с. 107-108]. В более поздней своей работе три зеркала из коллекции И.И. Копылова он относит к китайским [Байпаков, 2012, c. 65-66, 72, ил. VII]. Изображение (всего) одного зеркала из раскопок И.И. Копылова приводится в каталоге музейной экспозиции Государственного музея «Центр сближения культур» (далее - «Центр», прим. авт.) [«Культура и религия...», 2020, с. 56], где представлено пять зеркал. В экспозиции же Центра два из четырех зеркал представлены артефактами из раскопок И.И. Копылова (в чем удалось убедиться при посещении этого «Центра» в марте 2021 г.).

Наиболее развернутой публикацией зеркал из Талгара является статья К.Ю. Марковой [Маркова, 2013]. В ней реализуется тезис, сформулированный автором: «С помощью выделения ряда особенностей, присущих художественной культуре той или иной страны, предметы импорта удается идентифицировать с их местом производства» [Маркова, 2013, с. 36]. По результатам исследований были выделены четыре зеркала из Китая, два - из Ирана и одно - из Средней Азии [Маркова, 2013, с. 36-40]. Знакомство с публикацией И.И. Копылова [Копылов, 1988], архивными материалами [Копылов, 1986] мы приходим к предварительному заключению о том, что хронология производства зеркал может быть сужена до XII - первой половины XIII в. (возможно с конца ХІ в. по хронологии горизонта, определенного И.И. Копыловым), но не такой широкий диапазон (конец VIII - начало XIV в.), как это дается у К.Ю. Марковой. Местом производства на основе анализа данных о месте находки 
и знаний о бронзолитейном производстве на городище Талгар, а также данные об анализах металла, проведенных И.И. Копыловым в 1980-е гг,, можно однозначно судить о производстве зеркал в мастерских Талгара на местном сырье. По-видимому, кроме последнего (импортного) зеркала.

«Дом ювелира». В центре укрепленной части городища И.И. Копыловым были обследованы два достаточно зажиточных и крупных по площади землевладения: «дом ювелира» и «дом торевта». Начало этим раскопкам было положено в 1964 г., когда был заложен раскоп № 7 на правом берегу «поповского» арыка, там, где его пересекает дорога от восточных ворот к западным, мощеная окатанной галькой. При обследовании арыка был найден кусок кричного железа. Сначала была открыта стена из камней на глиняном растворе протяженностью 10 м, сохранившаяся на высоту 60-80 см, шириной 100-120 см. При разрушении она завалила остатки кладовой, где хранились запасы металла и различные орудия и предметы культа. В том числе более 100 кг кричного железа, тигли, сера, 40 целых и 150 фрагментов монет, большое разнообразие бронзовых ювелирных украшений, инструменты ювелираторевта [Копылов, 1978, с. 40].

Первое зеркало (рис. 2) из «дома ювелира» (диаметр - 118 мм, толщина - 1,5-2,0 мм, вес - 89,4 г) имеет форму не идеально круглого диска, лицевая сторона немного выпуклая. На тыльной стороне в центре расположен держатель полусферической формы, верхняя часть которого отбита. Сквозное отверстие держателя для шнура или ленты имеет диаметр 2,5-3,0 мм. Кромка зеркала имеет утолщение не более 1-1,5 мм. Зеркало лишено

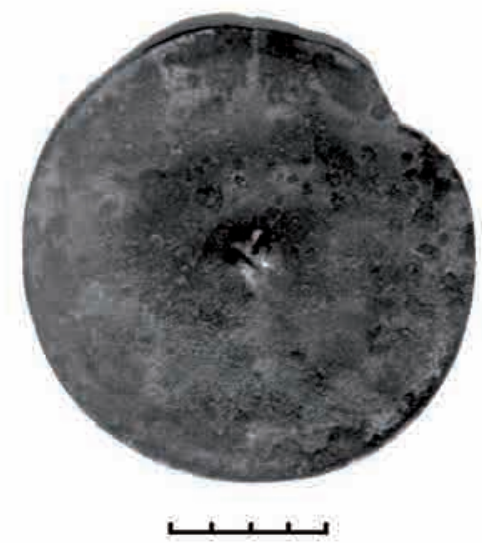

Рис. 2. Зеркало без орнаментации. "Дом ювелира», городище Талгар. XII - начало ХIII в. Фото из архива ГИК заповедника-музея "Иссык»

Fig. 2. Mirror without ornamentation. "House of jeweler", Talgar site. 12th - beginning of 13th century. Photo from archive of the State Historical Cultural Reserve-Museum of "Issyk"

какого-либо декоративного убранства. Его поверхность с обеих сторон амальгамирована тонким слоем сплава близкого по цвету к золоту [Копылов, 1988, с. 72]. Но лазерно-спектральный анализ показал отсутствие золота. Отлито зеркало из пластичной-монетной бронзы (табл. 1, ан. I). По покрытию поверхности амальгамой зеркало имеет аналогию с зеркалами конца IX - начала XII в. периода Тан и Сун [Стратанович, 1961, с. 48-51]. Зеркало ранее не публиковалось.

Второе зеркало (рис. 3) из дома ювелира имеет форму плоского диска диаметром 12,4 см, вес 156,4 г. Его бортик-закраина шириной 8-9 мм, слегка утолщен от 1,5 до 3,0 мм. Тыльная сторона богато украшена растительно-геометрическим орнаментом. В центре отлит держатель полусферической формы, верх которого отбит. Сквозное отверстие 


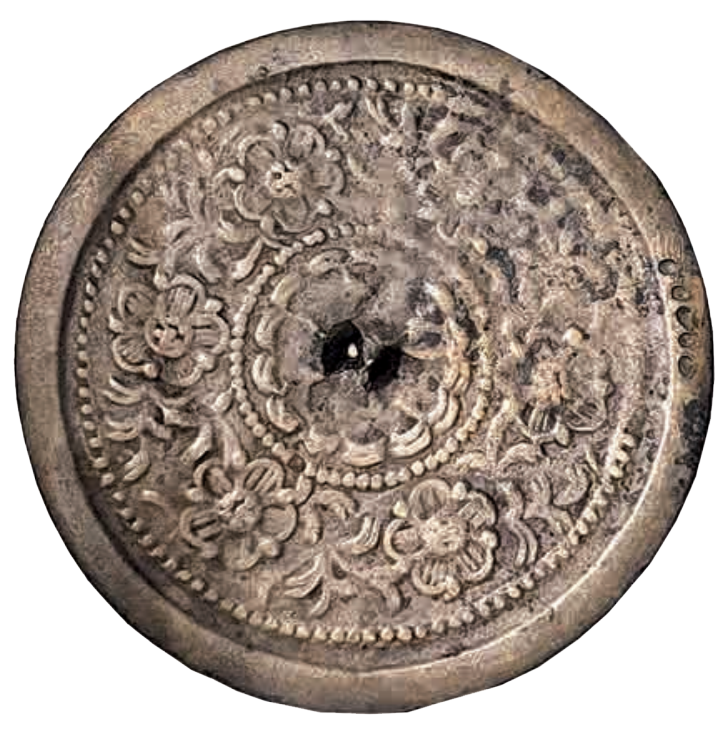

Рис. 3. Зеркало с растительным (китайским) орнаментом. «Дом ювелира», городище Талгар. Конеи XI - начало XIII в.

Экспозищия музея «Центр сближения культур» под эгидой ЮНЕСКО. Фото Б.А. Железнякова

Fig. 3. Mirror with plant (Chinese) ornament. "House of jeweler", Talgar site. $12^{\text {th }}$ - beginning of $13^{\text {th }}$ centuries. Exposition of the "Centre of the Rapproachment of Cultures" under UNESCO. Photo by B.A. Zheleznyakov

представлен в виде трех или четырех вертикально поставленных линий, окантованных сверху дугой [Копылов, 1988, с. 73]. Этот рельефный декор не везде исполнен четко. По мнению Л.И. Ремпеля, тип «шести стилизованных цветов» характерен для изделий, изготовленных в Китае [Ремпель, 1978, с. 162].

Отлито зеркало из твердой зеркальной бронзы, в которой более третьей части составляют присадки свинца - $20 \%$ и олова $15 \%$ (табл. 1 , ан. 2). Зеркало с подобным по стилю убранством, датирующимся X-XII вв., представлено в собрании зеркал Минусинского музея [ЛубоЛесниченко, 1975, с. 48].

Третье зеркало из дома ювелира, лицевая сторона которого имеет небольшую выпуклость, диаметром 14,5 см, весом 323,3 г, окантовано массивным бортиком высо-

для шнура или ленты имеет диаметр 4 мм. Вокруг шишечки держателя помещено стилизованное изображение 14-тилепестковой розетки, на 2 мм выше которой располагается точечный круг диаметром 4,5 см, состоящий из 60 маленьких шишечек, имитирующих зернь. Выше этого внутреннего круга расположен верхний круг-бордюр, состоящий из таких же 102 шишечек-точек. Между этими кругами помещена орнаментальная лента стилизованных веток с листьями и шестью пятилепестковыми розетками, между лепестками каждой из которых помещены шишечки-точки. Внутри цветка изображен круг из семи точек. Каждый лепесток цветка той $0,5-0,6$ см, шириной 0,9 см, имеющим в разрезе форму треугольника с высотой боковых граней $0,5-0,6$ см. Площадь круга внутри бордюрного ободка разделена по вертикали на две части двумя вписанными один в другой кругами, составленными из точек полусфер. В центре малого круга диаметром 4 см, состоящего из 46 шишечек, помещен держатель в виде полусферы высотой 0,8 см, со сквозным отверстием размером 0,5-0,7 см. Пространство между малым и большим бордюрным кругом диаметром $12 \mathrm{~cm}$ разделено на четыре части прямыми линиями, отходящими от внешней грани малого круга и доходящими во внутренней грани большого круга. 
Эти прямые линии-разделители составлены из тех же точек-шишечек. В двух линиях, расположенных на одной прямой, по 14 точек в каждой, в двух других линиях - по 15 точек. В каждом из образованных таким образом сегментов помещены по ветке трилистника и изображенными на них летящему журавлю или аисту с распростертыми крыльями, со схематично показанными на них перьями в виде 8-9 разрезов, расположенных в 2-3 ряда по длине крыльев, и вытянутыми ногами, на которых показаны пальцы в форме трех разрезов [Копылов, 1988, с. 74]. Все четыре птицы летят в одном направлении - направо (рис. 4).

Отлито зеркало из «зеркальной» бронзы, где присадка свинца состав-

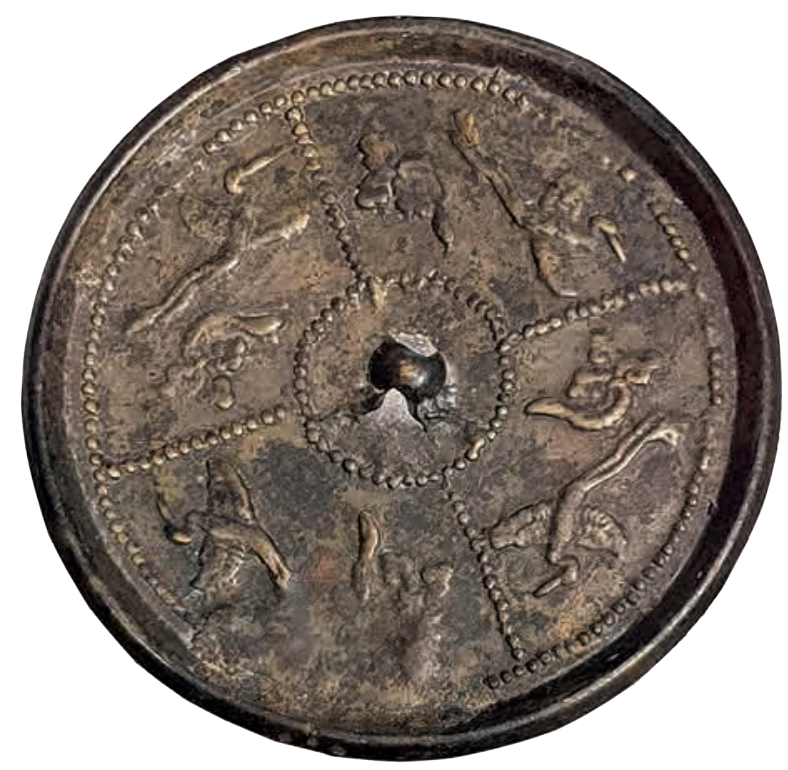

Рис. 4. Зеркало с растительно-орнитоморфным (китайским свадебным) орнаментом. «Дом ювелира», городище Талгар. ХІІ - начало ХІІІ в. Экспозищия музея «Центр сближения культур» под эгидой ЮНЕСКО. Фото Б.А. Железнякова

Fig. 4. Mirror with plant-ornithomorphic

(Chinese wedding) ornament. "House of jeweler", Talgar site. $12^{\text {th }}$ - beginning of $13^{\text {th }}$ centuries.

Exposition of the "Centre of the Rapproachment of Cultures" under UNESCO. Photo by B.A. Zheleznyakov ляет $10 \%$, а олова лишь $2 \%$ (табл. 1 , ан. 3). При отливке зеркала в одном из секторов (на фото - внизу) образовалась раковина, которую мастер залил заплаткой, в результате чего нарушилось изображение конца ног птицы и части трилистника.

Тем самым три зеркала, найденные в доме ювелира, представлены на рис. 5 (фото рисунка художника из архива И.И. Копылова).

Четвертое зеркало найдено в 1975 г. на глиняном полу жилого помещения северной половины «дома торевта», располагавшегося напротив дома ювелира, по северную сторону мостовой улицы. Как и предыдущее зеркало, оно имеет форму диска диаметром 13,2 см, с еле заметной выпуклостью лицевой стороны. Вес его 241,95 г. Внешняя грань диска оконтурена бортиком, имеющим в разрезе форму равнобедренного треугольника с размерами сторон: основание - 0,8 см, внешней грани 0,5-0,6 см. В центре внутренней плоскости помещен держатель полусферической формы высотой 0,8 см со сквозным отверстием размерами $0,4 \times 0,5$ см. Вся внутренняя плоскость заполнена рельефно отлитым нечетким (выделено нами - прим. авт.) орнаментом. На расстоянии 0,6 см от держателя помещен круг диаметра 3 см, составленный из 40 точек. От него отходят вверх прямые линии длиной 3,5 см, состоящие из 13-15 точек, доходящие до внутренней грани большого бордюрного круга 


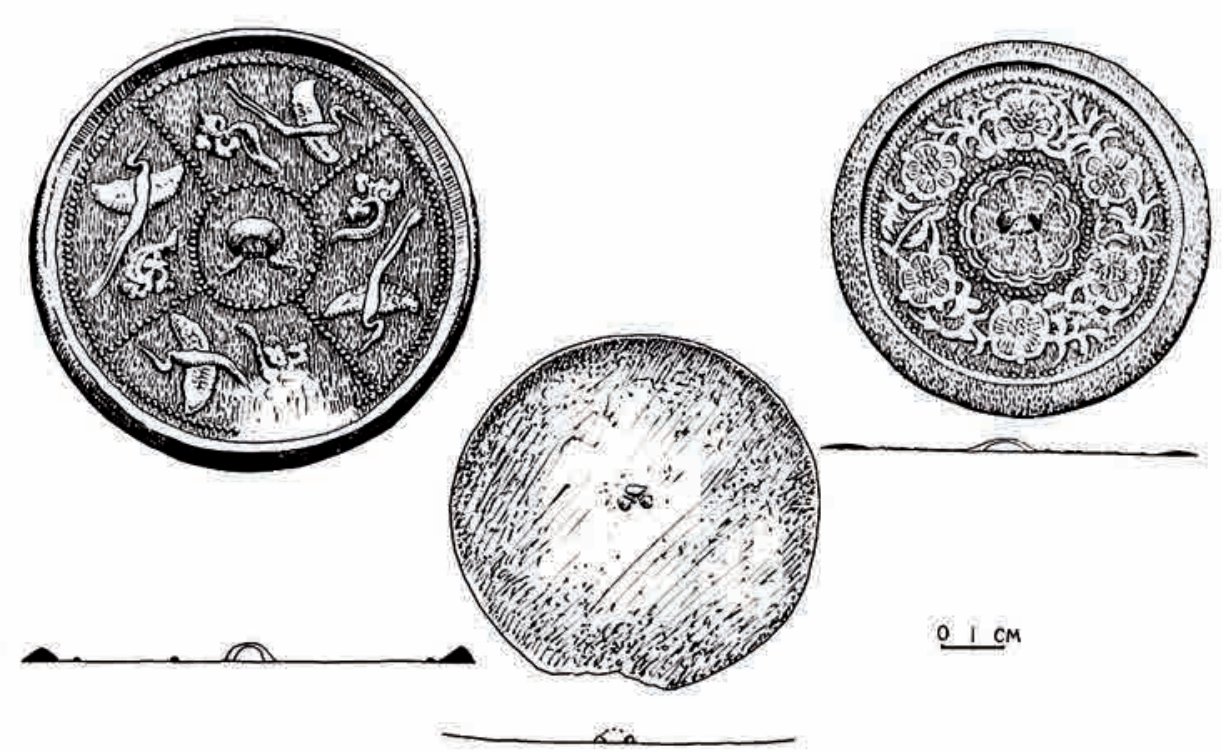

Рис. 5. Три бронзовых зеркала. «Дом ювелира», прорисовка. Фото из архива ГИК заповедника-музея «Иссык»

Fig. 5. Three bronze mirrors. "House of jeweler", drawing from the archive of the State Historical Cultural Reserve-Museum of "Issyk"

диаметром 10,5 см. Любопытен факт: некоторые из шишечек своей формой напоминают рисовые зерна. Этими линиями плоскость делится на четыре сектора [Копылов, 1988, с. 74].

В каждом из четырех секторов помещены по три летящие птицы с распростертыми крыльями и вытянутыми ногами как у аистов и у журавлей. Птицы расположены по вертикали в два круга - верхний и нижний. В нижнем ряду изображено по одной птице в каждом секторе. При этом в трех секторах птицы летят одна за другой, и лишь в одном секторе одна летит навстречу первой. В верхнем ряду в каждом секторе помещены по две птицы, разлетающиеся в разные стороны, т. е. к аистам противоположного сектора, что создает картину четырех пар, летящих навстречу друг к другу (рис. 6).
Изготовлено зеркало из твердой-зеркальной бронзы желтого цвета. Лабораторному анализу оно не подвергалось. Сохранность зеркала хорошая, поверхность слегка покрыта благородной патиной. Нечеткость изображения орнамента объясняется тем, что отливалось зеркало в форме многоразового использования. Культурный слой жилого комплекса, в котором найдено зеркало, датируется по нумизматическим материалам от конца XI до первой четверти XIII в. Его потерю/утрату логичнее относить к концу этого периода, хронологию изготовления восстановить сложнее, но также логичным выглядит вторая половина XII - начало XIII в. [Копылов, 1986, с. 5]. Зеркала с изображением двух пар противостоящих птиц относятся к категории свадебных зеркал, а орнамент, состоящий из парных птиц, 


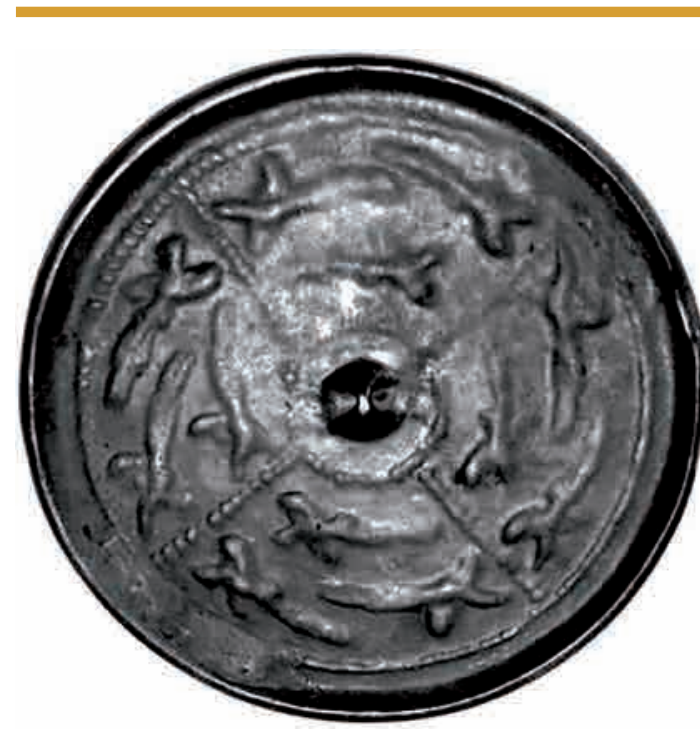

Рис. 6. Зеркало с нечетким орнаментом (12 птии). "Дом торевта», городище Талгар. XII - начало XIII в. Фото из архива ГИК заповедника-музея "Иссык»

Fig. 6. Mirror with fuzzy ornament (12 birds). "House of Torewt", Talgar site. $12^{\text {th }}$ - beginning of $13^{\text {th }}$ centuries. Archive of the State Historical Cultural Reserve-Museum of "Issyk"

символизирует счастливый брачный союз [Лубо-Лесниченко, 1975, с. 20]. Зеркала XII в. с аналогичным изображением летящих аистов или журавлей представлены в собрании зеркал Минусинской котловины [ЛубоЛесниченко, 1975, с. 27, рис. 72].

Пятое зеркало обнаружено в 1980 г. на полу жилого помещения домостроения, примыкающего с востока к дому торевта и состоящего с ним в одном жилом массиве, расположенном по северную сторону магистральной мостовой. Зеркало (рис. 7) имеет форму плоского диска диаметром 11,7 см, окантованного сверху бортиком высостой 0,3-0,4 см, шириной $0,5-0,6$ см. В центре тыльной стороны располагается держатель полусферической формы высотой 0,7 см со сквозным отверстием - ушком диа- метром 0,3 см. Лицевая плоскость украшена рельефно отлитым орнаментом, скомпанованным в три последовательно расположенных сверху вниз ряда. Верхний ряд, располагающийся ниже бортика на 0,5 см, представляет собой восемь полусфер-шишечек высотой $0,2-0,3$ см, шириной 0,5 см, отлитых на равном растоянии (3,5 см) друг от друга. Второй круг состоит из восьми медальонов, четыре из которых своей формой напоминают височные кольца или серьги, другие четыре медальона - замкнутые круги с вписанными в них квадратами, составленными из четырех рельефных угольников с точками-полусферами в центре каждой грани квадрата. Внутри каждого квадрата расположен рельефный круг из 19 шишечек. Третий, нижний, орнаментальный круг состоит из четырех накрест расположенных колец, составленных из восьми шишечек, отдельные из которые напоминают рисовые зерна [Копылов, 1986, с. 5].

Поверхность тыльной стороны покрыта патиной темного стального цвета. По наблюдениям Е.И. ЛубоЛесниченко, темная патина характерна для зеркал местного производства (Минусинской котловины) [ЛубоЛесниченко, 1975, с. 23]. Сохранность зеркала хорошая, но в одном месте образовалось сквозное отверстие от окисла. Аналитическим исследованиям зеркало не подвергалось [Копылов, 1986, с. 5].

Прямые аналогии зеркал по стилистике орнаментального убранства автору не известны. Хотя деление декора на концентрические зоны [Лубо-Лесниченко, 1975, с. 18] и украшение шишечками широко пред- 


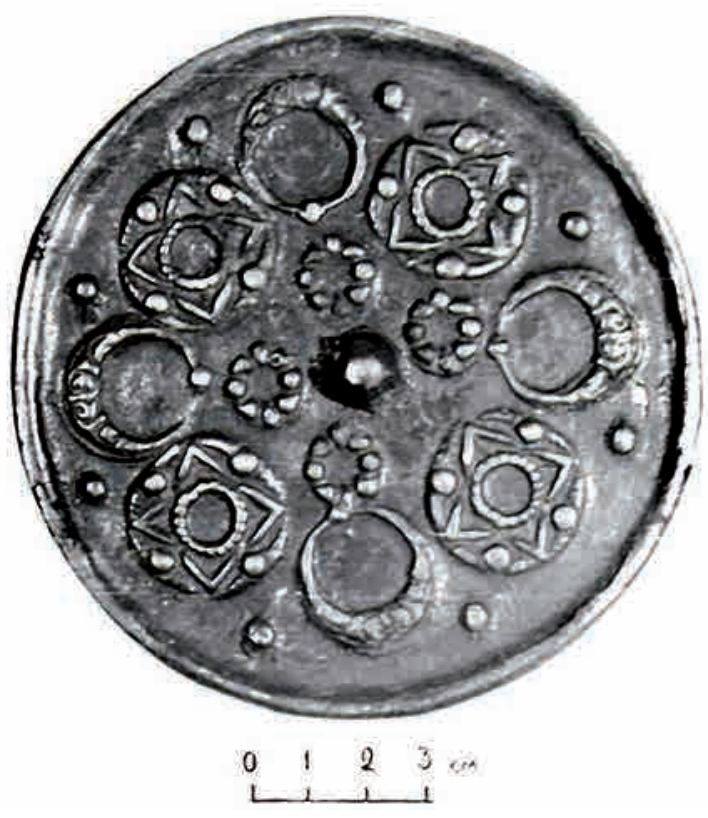

Рис. 7. Зеркало «с медальонами» (среднеазиатский орнамент). Соседнее жилище с «домом торевта», городище Талгар. ХII- начало ХІІІ в.

Фото из архива ГИК заповедника-музея «Иссык»

Fig. 7. Mirror "with medallions"

(Central Asian ornament). Neighboring dwelling with the "House of Torewt", Talgar site. 12 $12^{\text {th }}$ - beginning of $13^{\text {th }}$ centuries. Archive of the State Historical Cultural Reserve-Museum of "Issyk"
11,1 см (рис. 8). Вес половинки - 118 г. Лицевая сторона плоская с некоторым отклонением во внешнюю сторону - на краях утолщенного от 0,2 до 0,4 см бортика шириной 0,7 см. На внутренней плоскости в центре помещен держатель в виде брусочка размерами $0,4 \times 0,8 \times 1,1$ см. На расстоянии $1-1,3$ см от держателя помещен орнаментальный желобчатый круг диаметром 3,3 см; на расстоянии 1,2 см от закраины выполнен аналогичный круг диаметром 8,5 cм. Концентрический пояс между двумя желобчатыми кругами украшен растительным орнаментом, изображающим извивающуюся волнами и кольцами виноградную лозу с листьями [Копылов, 1986, с. 7].

В этот растительный орнамент вплетена благопожелательная надпись, испол- ставлены на зеркалах Минусинской котловины [Лубо-Лесниченко, 1975 , с. 12 , рис. 6], датирующихся большим диапазоном, начиная от II тыс. до н.э. и до XII, XIII веков включительно [Лубо-Лесниченко, 1975, с. 8-34, рис. $6,12,16-$ $18,48,49,76,102,103]$. К.Ю. Маркова считает его зеркалом из Средней Азии [Маркова, 2013, c. 38].

Шестое зеркало, представленное $1 / 2$ диска, имеет полный размер

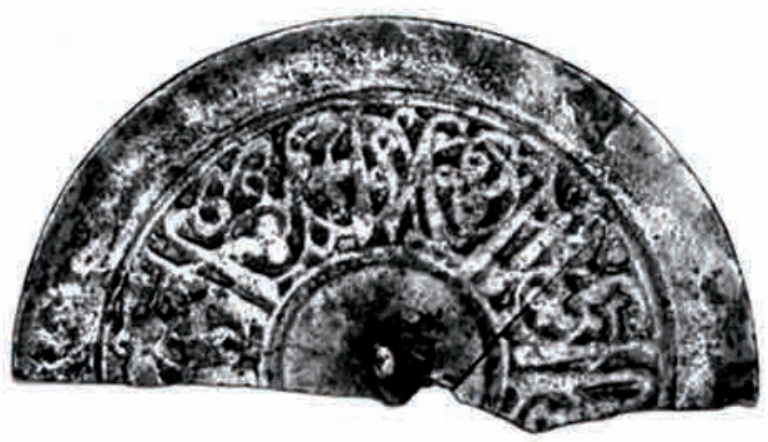

Рис. 8. Зеркало с арабской надписью: «Славы и успеха, и счастья!». Западный рабад городища Талгар. XII - начало XIII в.

Фото из архива ГИК заповедника-музея «Иссык»

Fig. 8. Mirror with the Arabic inscription "Glory and success and happiness!". Western Rabad of Talgar. 12th-beginning of $13^{\text {th }}$ centuries. Archive of the State Historical Cultural Reserve-Museum of "Issyk" 
ненная шрифтом «насх». Л.Т. Гюзельян интерпретировал ее как: «Славы и успеха и счастья!» [Копылов, 1986, с. 8]. Отлито зеркало из высокооловянисто-зеркальной бронзы (табл. I, ан. 5). Найдено зеркало в 1966 г. в западном пригороде в слое, датирующимся концом XI - началом XIII в. (нижняя терраса на подъеме из реки Тополевка, глубина 3-4 яруса, как подписано И.И. Копыловым на обратной стороне фото).

Аналогичные по форме круглые с петелькой зеркала, украшенные геометрически-растительным орнаментом, найдены в кимакскокыпчакских захоронениях X-XIII веков в Восточном Казахстане [Арсланова, 1968 , с. 100 , рис. $135,150,155]$.

Седьмое зеркало, размерами $6 \times 5,7$ см, содержит изображение четырех антропоморфных фигур (рис. 9). Они размещены по двое композиционно в левой и правой частях орнаментального поля в сидячих позах. Одежда и головные уборы выполнены в дальневосточной традиции. В нижней части изображена коленопреклоненная маленькая фигура с воздетыми к левосторонней (величественно восседающей) фигуре руками. Человек намеренно изображен вдвое меньше фигур, размещенных в левой и правой частях. В верхней части прослеживается нечеткое изображение человека/фигуры, композиционно тяготеющего к правой фигуре и выполненного в уменьшенном масштабе - удаленно, придающего всей композиции глубину и перспективу. Прямых аналогий, по К.М. Байпакову, зеркалу не найдено [Байпаков, 2012, c. 66, 68]. Возможно (если тема религиозная), здесь изображена семейная сцена: двое взрослых и двое детей. Детали изображений (по фото) - нечетки, несмотря на высокий рельеф. Известная полнотой охвата зеркал северной части Евразии монография Е.И. Лубо-Лесниченко «Привозные зеркала Минусинской котловины» (1975) аналогиями, близкими по стилистике и иконографии антропоморфных сюжетов, не располагает. Местонахождение зеркала в рукописи И.И. Копылова не указано и в результатах проведенных анализов не приводится.

Основываясь на материалах новой монографии по китайским зеркалам Евразии, можно уверенно говорить о том, что зеркало (диаметр 75 мм; Приморский край, РФ) относится к династии Цзинь (11151234 гг.). Сюжет: почитание и уважение родителей детьми. На зеркале из Приморья по бортику выбита плохо

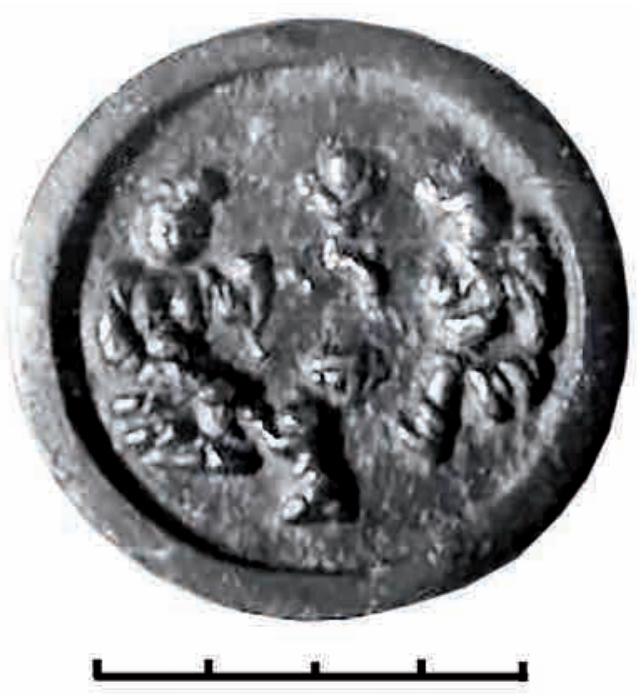

Рис. 9. Китайское зеркало, династия Цзинь. Городище Талгар, точное место находки его И.И. Копыловым не известно. Фото из архива ГИК заповедника-музея "Иссык»

Fig. 9. The Chinese mirror, the Jin Dynasty, Talgar site, precise location of the find made by I.I. Kopylov is unknown. Archive of the State Historical Cultural Reserve-Museum of "Issyk" 
различимая регистрационная надпись: «в (округе) Дань (проверено и) запротоколировано чиновником, таким-то». Округ находился на территории современной провинции Шэньси - самый центр Китая. Авторами [Оборин, Савостин, 2017, с. 196-197] было также отмечено, что прямой аналог встречен в Талгаре [Байпаков, 2012, с. 72]. В каталоге монографии приведен электронный адрес ресурса, где впервые было опубликовано изображение этого зеркалах [Оборин, Савостин, 2017, с. 509]. Монография уникальна своим охватом территории степной зоны Евразии и числом описанных случайных находок - 840 зеркал и их фрагментов. По-видимому, оба зеркала подлинные. Небольшой диаметр и значительная толщина ни в коей мере не способствовали разделению его на части (как известно, значительное число зеркал находится во фрагментированном состоянии).

Следует также отметить, что в последнее время появилась целая серия публикаций, посвященных анализу зеркал, которые отличает комплексный подход [Рогожинский, Джумабекова, 2017; Тишкин, Серегин, 2011; Серегин и др., 2021; и др.].

В связи с распространением религий в Жетысу, как западных, так и восточных, связанных, в том числе, со значительным влиянием киданей и культуры государства Ляо, в предмонгольское время в Талгаре отмечено серьезное скопление сюжетов со всей Азии: Иран, Средняя Азия, Китай и Дальний Восток. Однако все зеркала были изготовлены в Талгаре из местного сырья. Отметим, что лишь последнее зеркало не было подвергнуто анализу материала и есть основания считать, что И.И. Копылов располагал данными анализа, но не представил ни в рукописи [Копылов, 1986], ни в статье [Копылов, 1988].

О степени совершенства бронзолитейного ремесла в городе свидетельствует высокое качество бронзы и четкость отлитого декора на четырех из пяти зеркалах, лишь зеркало из «дома торевта», «не соответствует» остальным по тому параметру. Результаты анализов компонентного состава сплавов, из которых изготовлены зеркала, свидетельствуют, что отлиты они на высоком по тем временам техническом уровне развития цветной металлургии и бронзолитейного дела в особенности, отвечающим требованиям, предъявленным к отливке зеркал.

\section{Обсуждение результатов}

Зеркала древнего Талхира изготовлены из местного сырья, на что указывает однообразие естественных примесей, характерных для одного или близко расположенных рудных источников, как об этом заключал И.И. Копылов (табл. 1). Наблюдения над компонентным составом бронз показывает, что в абсолютном большинстве подвергнутых анализам изделий из Талхира, в том числе и в двух зеркалах, присадка свинца содержится в бо́льших размерах, чем олова. Объясняется это, во-первых, тем, что свинец выполняет функцию отвердителя сплава столь же успешно, как и олово. И, во-вторых, и это главное, рудный источник галенита расположен поблизости от города Талхира - в верховьях реки Талгар, а залежей касситерита здесь нет и олово нужно было где-то приобретать. Обнаруженные на городище куски медного колчедана и галенита, добываемых в верховьях реки Талгар, имеют весьма высокий процент содержания металла. Все это благоприятствовало развитию цвет- 
ной металлургии в целом и бронзолитейного ремесла в частности (на местном сырье) [Копылов, 1986, с. 5; 1988, c. 71, 77]. Наиболее характерным признаком бронз Илейской долины является присутствие висмута как сопутствующего компонента в рудах меди, свинца, вольфрама (табл. 1, ан. 1-3,5), которого в бронзах Северного и Восточного Казахстана совершенно нет [Копылов, 1988, с. 77].

Поскольку эти зеркала обнаружены в верхнем горизонте культурного слоя городища, относящегося ко второму периоду жизни города (конец XI - первая половина XIII в.), когда, в частности, имела место экспансия киданей в Семиречье/Жетысу, то можно полагать, что появление в городе Талхир зеркал с аистами-журавлями, считавшимися на Дальнем Востоке символами счастья и долголетия [ЛубоЛесниченко, 1975, с. 26], связано с их военно-политическим господством в городе киданей. Данный факт подтверждается находкой в «доме торевта» аптекарского сосуда из кашина, на донце которого сделана проявляющейся тушью надпись малым киданьским письмом [Копылов, 1988, с. 77].

Описанные выше зеркала интересны не только с точки зрения техники их производства как показатель степени развития бронзолитейного ремесла, но и своим орнаментальным убранством, эпиграфикой, указывающими на существование социальноэкономических и культурно-политических связей населения города Талхира на определенные направления в развитии культуры: духовной, художественной. Факты, изложенные в рукописи И.И. Копылова, значительно дополняют наши представления по (длительной) истории изучения Талгара, его ремесла.
Как известно, бронзовые зеркала широко использовались в утилитарных и в сакральных целях в древности и средневековье. Утилитарные их функции очевидны. К «выявленным» сакральным функциям относились, главным образом, хранение «супружеских уз» при вынужденном расставании как при жизни, так и при смерти одного из супругов, тогда половинка зеркала вкладывалась в могилу. В обоих случаях зеркало намеренно ломали, стараясь получить две половины [Баринова, 2012]. В случае вынужденного расставания при жизни, в случае измены, половинка зеркала «превращалась в сороку» и рассказывала второму супругу/любовнику об этом факте. В случае вложения половинки в могилу, второй супруг мог легко найти его в загробном мире, как об этом писал Б.А. Литвинский [Баринова, 2012, с. 60].

Тем самым, по-видимому, благодаря широкому распространению подобных воззрений, во всей Центральной Азии заказы на производство зеркал талгарскими и другими мастерами - ювелирами и торевтами были очень распространены. А вопросы археологов о том, почему так часто находятся «разбитые» зеркала, половинки и меньшие фрагменты - обретают ответы. Кроме того, становится ясным, почему были востребованы зеркала - многократно воспроизведенные в ремесленных мастерских, изображения на которых потеряли изначальную четкость.

\section{Заключение \\ В начале-середине 1980-х гг.} И.И. Копылов сделал современные (на тот момент) анализы состава металла бронзы. К слову, еще ранее и Е.И. Лубо-Лесниченко отмечал 
резкую визуальную разницу между местными и привозными зеркалами (для его региона): «Привозные зеркала имеют характерный для танского времени белый металл и тщательно выполненный орнамент с проработанными деталями. Как правило, они массивны. У местных отливок орнамент обычно стёртый или размытый, часто с плохо различимыми деталями. Металл местных зеркал, в отличие от танских, жёлтый и, как правило, покрыт тёмной патиной. Это различие в составе металла подтверждается спектральным анализом, дающим точный критерий для разделения этих двух больших групп» [Лубо-Лесниченко, 1975 , с. 23]. Очевидно, что И.И. Копылов пошел тем же путем и выделили местные зеркала по цвету патины и факту «размытости» рельефа. Видимо, состав металла или какие-то другие особенности значительно «роднили» Минусинский и Иле-Алатауский металл и отличали по внешнему виду предметы, из него произведённые, от производителей Китая и Ирана, имевшие значительно больший выбор для формирования состава металла для своих зеркал и делали его белым.

Тем самым помимо вопросов, связанных с этнокультурной принадлежностью орнаментации зеркал, например, к иранским, китайским, среднеазиатским образцам, ранее уже успешно решенных другими исследователями, в статье решаются вопросы, связанные с местным производством обнаруженных на городище зеркал из местного сырья. В последние десятилетия исследований городища Талгар Т.В. Савельевой [Маркова, 2013] было найдено еще несколько бронзовых зеркал, судя по цвету металла также местного производства. Очевидно, что ремесленники Талхира производили продукцию, востребованную у средневекового потребителя на местном сырье [Рогожинский, Железняков, 2019]. Торевты и ювелиры могли быть наиболее подвижными среди всего цеха ремесленников, передавать секреты мастерства исключительно по династийной линии, судя по результатам исследований И.И. Копылова, быть наиболее приближенными к местной элите на протяжении веков. Бронзолитейное производство в Талгаре, зафиксированное И.И. Копыловым в раскопах № 7, 8 местного торевта и ювелира, развивалось параллельно с другими ремеслами, обслуживавшими значительный спрос этого участка Шелкового пути, в частности, с керамическим [Кузнецова, 2007; Мухтарова и др., 2020].

В настоящее время сотрудниками заповедника-музея «Иссык» проводится подготовка к публикации материалов из поступившего на хранение архива И.И. Копылова. Материалы по бронзовым зеркалам были им опубликованы [Копылов, 1988], но накопившиеся за время публикации материалы, по каким-то причинам, никак не учитывавшим первую публикацию материала, а также значительные детали по последнему зеркалу, сделали данную публикацию актуальной, если не несколько запоздалой. Кроме того, в статье приводится определение мест экспозиции зеркал в настоящее время. Сопоставляются данные относительно местного производства зеркал или их импорта. Тем самым данная статья учитывает все известные публикации и архивные источники по бронзовым зеркалам Талгара, известным на сегодняшний момент. 


\section{ЛИТЕРАТУРА}

1. Арсланова Ф.Х. Памятники Павлодарского Прииртышья (VII-XII вв.) // Новое в археологии Казахстана / отв. ред. М.К. Кадырбаев. Алма-Ата: Наука, 1968. C. 98-111.

2. Байпаков K.M. Казахстан // Художественная культура Центральной Азии и Азербайджана IX-XV вв. Т. III. Торевтика. Самарканд-Ташкент: МИЦАИ, 2012. С. 29-68.

3. Байпаков К.М., Савельева Т.В., Чанг К. Средневековые города и поселения Северо-Восточного Жетысу. Алматы: Credo, 2005. 188 с.

4. Баринова Е.Б. Зеркала как источник по истории контактов народов Средней Азии с Китаем в древности и средневековье // Вестник РУДН. Сер. Всеобщ. ист. 2012. № 4. C. 57-92.

5. Городецикий В.Д. Талгарское городище // Известия Средазкомстариса. 1928. Вып. 3. С. 49-55.

6. Камалдинов И.Р., Савельева Т.В. Направления Великого Шелкового пути в Илийской долине (по археологическим источникам) // Электронный научный журнал «edu.e-history.kz». 2019. № 1 (17). URL: https://edu.e-history.kz/ru/publications/view/1221 (дата обращения: 19.02.2021).

7. Копылов И.И. К вопросу о составе древних бронз Семиречья // Ученые записки АГПИ им. Абая. Сер. гум. наук. 1955. Т. 9. С. 38-51.

8. Копылов И.И. Культура древнего Талгара. Алма-Ата, 1978. 49 с. Рукопись. Личный фонд И.И. Копылова // Фонды ГИКЗМ «Есик». КП ЕҚМ ҒКҚ 220.

9. Копылов И.И. Зеркала древнего Талхира (Талгара). Рукопись. 1986. 10 с. Личный фонд И.И. Копылова // Фонды ГИКЗМ «Есик». КП ЕҚМ ҒКҚ 220.

10. Копылов И.И. Отчет об археологических раскопках на Талгарском городище в 1986 году. Казахский пединститут им. Абая. Алма-Ата, 1987 // Архив Института археологии им. А.Х. Маргулана. Ф. 11, оп. 2, д. 2147, 32 л. + таб.

11. Копылов И.И. Зеркала из Талгарского городища (к проблеме этнокультурных контактов) // Материалы по этнокультурным связям народов Дальнего Востока в средние века: сб. ст. / отв. ред. Э.В. Шавкунов. Владивосток: ДВО АН СССР, 1988. C. $70-78$.

12. «Культура и религия на Великом Шелковом пути» экспозиция каталогы. Құрастырушы: Халықаралық мәдениеттерді жақындастыру орталығы. Алматы: «Жамбыл», 2020. 160 б.

13. Кузнецова О.В. Поливная керамика Талгара // Известия НАН РК. Сер. обществ. наук. 2007. № 1. С. 102-106.

14. Лубо-Лесниченко Е.И. Привозные зеркала Минусинской котловины (К вопросу о внешних связях древнего населения Южной Сибири). М.: Наука, 1975. 165 с.

15. Маргулан А.Х., Агеева Е.И. Археологические работы и находки на территории Казахской ССР (с 1926 по 1946 гг.) // Известия АН КазССР. Сер. археол. 1948. Вып. 1. С. 125-135.

16. Маркова К.Ю. Бронзовые зеркала северо-восточного Семиречья в эпоху развития городской культуры (конец VIII - начало XIV в.) // Вестник Кемеровского госуниверситета. 2013. № 4 (56). С. 36-40.

17. Мухтарова Г.Р., Железняков Б.А., Тулегенов Т. Средневековая керамика поселения Рахат (по материалам исследований 2019-2020 гг.) // Археология Казахстана. 2020. № 3 (9). C. 92-102. DOI 10.52967/akz2020.3.9.92.102

18. Оборин Ю.В., Савосин С.Л. Китайские бронзовые зеркала. Корпус случайных находок. Электронное издание. Красноярск-М., 2017. 527 с.

19. Ремпель Л.И. Искусство Среднего Востока. Избранные труды по истории и теории искусств. М.: Советский художник, 1978. 286 с.

20. Рогожинский А.Е., Джумабекова Г.С. Комплекс уникальных гравюр сакской эпохи из Кулжабасы (культурно-исторические связи и датировка) // Металлические котлы ранних кочевников Жетысу. Коллективная монография / отв. ред. Г.С. Джумабекова, Г.А. Базарбаева. Алматы: Институт археологии им. А.Х. Маргулана, 2017. С. 111-132. 
21. Рогожинский А.Е., Железняков Б.А. Клейма и тамги на двух серебряных сосудах из долины Шу и Монголии // Отан тарихы. 2019. № 3 (87). С. 166-182.

22. Савельева T.B. Исследования средневекового Тальхира в 2005 году (раскопы у восточного въезда) // Известия НАН РК. Сер. обществ. наук. 2006. № 1 (252). C. 171-176.

23. Савельева Т.В., Зиняков Н.М., Воякин Д.А. Кузнечное ремесло СевероВосточного Семиречья. Алматы: Гылым, 1998. 128 с.

24. Савельева Т.В., Зиняков Н.М., Камалдинов И.Р. Кузнечное ремесло средневековых городов Илейской долины (историография и датирование чугунных изделий) // Археология Казахстана. 2020. № 3 (9). C. 70-91. DOI 10.52967/akz2020.3.9.70.91

25. Серегин Н.Н., Чистякова А.Н., Монгуш К.М. Редкое металлическое зеркало чжурчжэньского времени из Тувы // Теория и практика археологических исследований. 2021. T. 33. № 1. C. 172-188. DOI 10.14258/tpai(2021)1(33).-11.

26. Стратанович Г.Г. Китайские бронзовые зеркала: их типы, орнаментация и использование // Восточноазиатский этнографический сборник. Вып. 2. Тр. Института этнографии АН СССР, новая серия. Т. 73. М.: Наука, 1961. С. 47-76.

27. Тишкин А.А., Серегин Н.Н. Металлические зеркала как источник по древней и средневековой истории Алтая (по материалам Музея археологии и этнографии Алтая Алтайского государственного университета). Барнаул: «Азбука», 2011. 144 с.

\section{REFERENCES}

1. Arslanova, F. Kh. 1968. In: Kadyrbayev, M. K. (ed.). Novoe v arheologii Kazahstana (New in archaeology of Kazkakhstan). Alma-Ata: "Nauka" Publ., 98-111 (in Russian).

2. Baipakov, K. M. 2012. In: Hudozhestvennaya kultura Centralnoy Azii i Azerbaidzhana IX-XVvv. (Art culture of Central Asia and Azerbaijan). T. III. Samarkand-Tashkent: International Institute for Central Asian studies, 29-68 (in Russian).

3. Baipakov, K. M., Savelyeva, T. V., Chang C. 2005. Srednevekovye goroda i poseleniya Severo-Vostochnogo Zhetysu (Medieval towns and settlements of North-East Zhetysu). Almaty: "Credo" Publ. (in Russian).

4. Barinova, E. B. 2012. In: RUDN Journal of World History, 4, 57-92 (in Russian).

5. Gorodetskiy, V. D. 1928. In: Izvestiya Sredazkomstarisa (News of Sredazkomstaris), 3, 49-55 (in Russian).

6. Kamaldinov, I. R., Savelyeva, T. V. 2019. In: «edu.e-history.kz», 1 (17). URL: https://edu.e history.kz/ru/publications/view/1221 (in Russian).

7. Kopylov, I. I. 1955. In: Uchenye zapiski AGPI im. Abaya. Seriya gumanitarnyh nauk. (Scientific notes of the Abay Alma-Ata State Pedagogical Institute. Ser. hum. Sciences), 9, 38-51 (in Russian).

8. Kopylov, I. I. 1978. In: Funds Issyk State Historical and Cultural Reserve-Museum, КП ЕҚМ ҒКҚ 220 (in Russian).

9. Kopylov, I. I. 1986. In: Funds Issyk State Historical and Cultural Reserve-Museum, КП ЕҚМ ҒКҚ 220 (in Russian).

10. Kopylov, I. I. 1987. In: A.Kh. Margulan Archeology Institute Archive. F. 11, op. 2 , d. 2147 (in Russian).

11. Kopylov, I. I. 1988. In: Shavkunov, E. V. (ed.). Materialy po etnokulturnym svyazyam narodov Dalnego Vostoka v srednie veka (Materials on ethnocultural relations of the peoples of the Far East in the Middle Ages). Vladivostok: Far East Branch of the USSR Academy of Sciences, 70-78 (in Russian).

12. «Kultura i religiya na Velikom Shelkovom puti» ekspoziciya katalogy (Culture and religion on the Great Silk Road). 2020. Almaty: "Gylym" (in Russian).

13. Kuznetsova, O. V. 2007. In: Izvestiya NAN RK. Ser. obshchestv. Nauk (News of the NAS RK. Ser. societies. sciences), 1, 102-106 (in Russian).

14. Lubo-Lesnichenko, E. I. 1975. Privoznye zerkala Minusinskoj kotloviny (K voprosu o vneshnih svyazyah drevnego naseleniya Yuzhnoj Sibiri) (Imported mirrors of Minusa) Moscow: "Nauka" Publ. (in Russian). 
15. Margulan, A. Kh., Ageeva, E. I. 1948. In: Izvestiya AN Kaz.SSR. Ser. arheol. (News of the Academy of Sciences of the Kazakh SSR. Ser. archeol.), 1, 125-135 (in Russian).

16. Markova, K. Yu. 2013. In: Vestnik Kemerovskogo GU (Bulletin of Kemerovo State University), 4 (56), 36-40 (in Russian).

17. Mukhtarova, G. R., Zheleznyakov, B. A., Tulegenov, T. 2020 In: Kazakhstan Archeology, 3 (9), 82-92 (in Russian).

18. Oborin, Yu. V., Savosin, S. L. 2017. Kitayskie bronzovye zerkala. Korpus sluchaynyh nahodok (Chinese bronze mirrors. Corpse of occasion finds). Krasnoyarsk-Moscow (in Russian).

19. Rempel, L. I. 1978. Iskusstvo Srednego Vostoka. Izbrannye trudy po istorii i teorii iskusstv (Art of Middle East. Selected contributions). Moscow: "Sovetskiy khudozhnik" Publ. (in Russian).

20. Rogozhinskiy, A. E., Jumabekova, G. S. 2017. In: Jumabekova, G. S., Bazarbayeva, G. A. (eds.). Metallicheskie kotly rannih kochevnikov Zhetysu (Metal cauldrons of the early nomads of Jetysu). Almaty: A.Kh. Margulan Archeology Institute (in Russian).

21. Rogozhinskiy, A. E., Zheleznyakov, B. A. 2019. In: Otan tarihy (The homeland history), 3 (87), 166-182 (in Russian).

22. Savelyeva, T. V. 2006. In: Izvestiya NAN RK. Ser. obshchestv. nauk (News of the NAS RK. Ser. societies. sciences), 1 (252), 171-176 (in Russian).

23. Savelyeva, T. V., Zinyakov, N. M., Voyakin, D. A. 1998. Kuznechnoe remeslo Severo-Vostochnogo Semirechiya (The smithcraft of North-East Semirechie). Almaty: "Gylym" Publ. (in Russian).

24. Savelyeva, T. V., Zinyakov, N. M., Kamaldinov, I. R. 2020. In: Kazakhstan Archeology, 3 (9), 70-91. DOI: 10.52967/akz2020.3.9.70.91 (in Russian).

25. Seregin, N. N., Chistyakova, A. N., Mongush, K. M. 2021. In: Theory and practice of archaeological research, vol. 33, № 1, 172-188. DOI 10.14258/tpai(2021)1(33).-11 (in Russian).

26. Stratanovich, G. G. 1961. In: Vostochnoaziatskiy etnograficheskiy sbornik (East Asian Ethnographic Collection), 2, 47-76 (in Russian).

27. Tishkin, A. A., Seregin, N. N. 2011. Metallicheskie zerkala kak istochnik po drevney i srednevekovoy istorii Altaya (po materialam Muzeya arheologii i etnografii Altaya Altayskogo gosudarstvennogo universiteta) (Metal Mirror as a Source on the Ancient and Medieval History of Altai (Based on Materials from the Museum of Archaeology and Ethnography of Altai, Altai State University)). Barnaul: “Azbuka” Publ. (in Russian).

\footnotetext{
Мүдделер қақтығысы туралы ақпаратты ашу. Авторлар мүдделер қақтығысының жоқтығын мәлімдейді. / Раскрытие информации о конфликте интересов. Авторы заявляют об отсутствии конфликта интересов. / Disclosure of conflict of interest information. The authors claims no conflict of interest.

Мақала туралы ақпарат / Информация о статье / Information about the article.

Редакцияға түсті / Поступила в редакцию / Entered the editorial office: 05.04.2021.

Рецензенттер мақұлдаған / Одобрено рецензентами / Approved by reviewers: 25.05.2021.

Жариялауға қабылданды / Принята к публикации / Accepted for publication: 28.05.2021.
} 